\title{
INVESTIGATION OF OPTIONS TO COMPENSATE FOR FUEL QUALITY VARIATION BY A COMBINATION OF SEVERAL CONTROL INTERVENTIONS AT ONCE
}

\section{MARCEL ŠKAROHLÍD}

Josef Božek Research Centre of Engine and Automotive Engineering, Technická 4, 16607 Prague 6, Czech Republic, Tel.: +420 224351827, E-mail: marcel.skarohlid@fs.cvut.cz

\section{SHRNUTI}

Tématem tohoto článku je zkoumání možností kompenzace kolísání kvality paliva kombinací několika regulačních zásahů najednou. Takto jsou odvozeny pokyny, jak zajistit flexibilitu motoru ohledně paliva co nejefektivnějším způsobem. Za potenciální regulační parametry jsou uvažovány úhel předstihu zážehu, nastavení plnícího tlaku a poměr recirkulace výfukových plynů. Matematická simulace je použivána jako preferovaný způsob zkoumání s cílem získat co nejvíce obecné výsledky. Používané simulační nástroje byly kalibrovány pomocí experimentálních dat z testovaného motoru.

KLICČOVÁ SLOVA: SLOŽENÍ PLYNNÉHO PALIVA, VÝKON, ÚČINNOST, KLEPÁNÍ, PRODUKCE ŠKODLIVIN, GT-POWER, ITERAČNII REGRESNÍ METODA, ÚHEL PŘEDSTIHU ZÁŽEHU, PLNIICI TLAK, RECIRKULACE VÝFUKOVÝCH PLYNŮ

\section{ABSTRACT}

The main topic of this paper is investigation of options to compensate for fuel quality variation by a combination of several control interventions at once. In this manner guidelines are derived on how to most effectively ensure fuel flexibility of the engine. Ignition timing, boost pressure adjustment and EGR rate are considered as potential control parameters. The mathematical simulation is used as a preferred method of investigation in order to obtain as much generalized results as possible. The utilized simulation tools were calibrated using experimental data from the tested engine.

KEY WORDS: GASEOUS FUEL COMPOSITION, POWER, EFFICIENCY, ENGINE KNOCK, PRODUCTION OF POLLUTANTS, GT-POWER, ITERATIVE REGRESSION METHOD, IGNITION TIMING, BOOST PRESSURE, EXHAUST GAS RECIRCULATION

\section{INTRODUCTION}

Unlike the exploitation of conventional liquid fuels, the designers, manufacturers and users of gas fuelled engines have to take into account a certain fluctuation in fuel composition. Natural gas composition varies all across the European continent and depends on the gas production field location. The higher the target values of engine parameters, the stronger the deterioration of engine behavior that can be expected as soon as fluctuations in fuel quality occur. On the other hand, advanced engine control systems offer the ability to compensate for fuel quality fluctuations, or at least to minimize its negative influence by ensuring optimum adjustment for each fuel.

Some fuel-specific impacts do not require modification of the control algorithm, especially in the case of feedback control. Closed-loop $\lambda$-control, ignition retardation at knock occurrence or protection of turbocharger against over speeding will work with any fuel as long as plausible feedback is available. In these cases it is only necessary to verify the plausibility of relevant signals ( $\lambda$ sensor voltage, frequency spectrum of knock sensor signal) while the engine operates on the fuel blends of various composition.

The knowledge acquired from previous experimental and simulation activities of the author's workplace defines the inevitable negative impacts (if any) of the exploitation of fuel of poor quality or (from the opposite point of view) determines limits of acceptable worsening of the gas quality as a contribution to the activities aimed at the introduction of gas quality standards. There are conditions which call for modification of the control algorithm.

Throughout the load range, ignition timing has to be arranged to obtain optimum efficiency even if the fuel combustion characteristics change. The EGR rate (if any) has to be adjusted just to a level ensuring sufficient protection of engine parts against excessive thermal loading without causing excessive deterioration of engine efficiency. There is no feedback usable as control inputs under such conditions. Therefore, it is necessary to determine not only the engine response to the fuel composition at a given

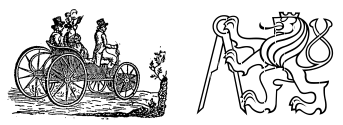

Investigation of Options to Compensate for Fuel Quality Variation by a Combination 
adjustment, but also the sensitivity of the engine to adjustment of the control elements while fuelled by gaseous blends of various compositions. The topic of this paper is investigation of the options to compensate for fuel quality variation by a combination of several control interventions at once.

This article follows an article published in the previous issue [1] of this journal and used the same simulation engine model, methods and tools.

\section{ENGINE MODEL DESCRIPTION}

The tested engine is of a class of engine typically used to drive LD trucks. The engine accessory layout and its initial adjustment are arranged with the aim of obtaining a range and assortment of experimental data necessary to describe the impact of fuel composition in a sufficiently comprehensive way. The parameters of the engine are briefly summarized in Table 1.

The $0-1 \mathrm{D}$ mathematical model GT-Power [2] is used for modeling the tested gas turbocharged engine. The GT-Power model layout (which is assumed from [3]) of the whole $4 \times \varnothing 102 / 120$ engine with turbocharger, EGR valve and cooler, and virtual sensors and controllers is shown in Figure 1. The engine model contains a complete geometry of engine peripherals and accessories (transferred into the model from reality), a complete set of correction coefficients and complete turbine and compressor maps. The steady state compressor and turbine maps were obtained from the turbocharger manufacturer R\&D department. The discharge coefficients of both exhaust and intake ports were determined experimentally at steady flow on a test rig. Valve lift profiles were measured and imposed together with operating valve lash correction derived from a preliminary common evaluation of in cylinder pressure and manifold pressures within the low pressure part of the working cycle. An in-house routine was created for description of wall heat transfer [4]. It applies the well-known (and for SI engines well-proven) Eichelberg's formula. The definition of operating conditions is imposed as a set of inputs expressed either in terms of actuator positions or as physical values of particular quantities. The set of outputs (containing both integral quantities and angle resolved patterns - formatted according to user requirements) is generated by forward simulation running in iterative mode until the convergence conditions are reached. The complete engine model was used primarily for engine behavior description under various conditions. The matrices of model outputs, indexed according to the values of particular elements of simulation inputs, should serve as a comprehensive and systematic description of the influence of fuel composition, operating conditions and controls adjustments.

The most important part of the model is the introduction of a new approach for determination of heat release patterns [5]. The predictive ability of any forward engine working cycle simulation is crucially dependent on the quality and plausibility of the heat release (HR) curve determination [6].

The application of the method started from a reference cycle. The reference heat release pattern is then either pushed or stretched along the crank-angle coordinate. This is performed by shifting several characteristic points on the HR pattern, multiplying its distance from the spark discharge point by a recalculation coefficient. Recalculation coefficients for each point on the HR pattern are determined as a product of effect factors. Each effect factor describes one particular circumstance which influences HR scope. The set of effect factors was chosen according to the

TABLE 1: Description of the Tested Engine

TABULKA 1: Popis testovaného motoru

Engine Notation $4 \times \varnothing 102 / 120$

Basic Engine Geometry

\begin{tabular}{lc} 
Cylinder \# & 4 \\
\hline Bore & $102 \mathrm{~mm}$ \\
\hline Stroke & $120 \mathrm{~mm}$ \\
\hline Displacement & $3.92 \mathrm{dm}^{3}$
\end{tabular}

\begin{tabular}{lc}
\hline Compression Ratio & 12 \\
\hline Valve \# / Cylinder & 4 \\
& Engine Performance \\
Maximum Speed & $2800 \mathrm{~min}^{-1}$ \\
\hline Maximum Torque & $600 \mathrm{Nm}$ \\
& $@ 1500-1600 \mathrm{~min}^{-1}$ \\
\hline
\end{tabular}

Maximum Power

$125 \mathrm{~kW}$

@ $2400-2800$ min $^{-1}$

\begin{tabular}{lll} 
& Turbocharger \\
Make & CZ C12 \\
\hline
\end{tabular}

\begin{tabular}{lc}
\hline Control & Variable Turbine Geometry \\
\hline Maximum Boost Pressure & 2.4 bar
\end{tabular}

\begin{tabular}{lc}
\hline Maximum Boost Pressure & 2.4 bar \\
\hline Intercooler & Air-to-Water
\end{tabular}

\begin{tabular}{lr} 
& Mixture Formation \\
\hline Arrangement & Common (central) mixer
\end{tabular}

\begin{tabular}{lc} 
Arrangement & Common (central) mixer \\
\hline Excess-Air Ratio & $\lambda=1$ \\
\hline Excess-Air Ratio Control & Manual (any value) or Closed Loop $(\lambda=1)$ \\
\hline Exhaust Gas Recirculation & Cooled; Low Pressure
\end{tabular}

Control units

Electronic Control Unit $\quad \begin{aligned} & \text { Distributed, Independent: } \lambda \text {-control; } \\ & \text { Ignition Control; Mixture Throttle Control; }\end{aligned}$ VTG Rack Control; EGR Throttle Control 


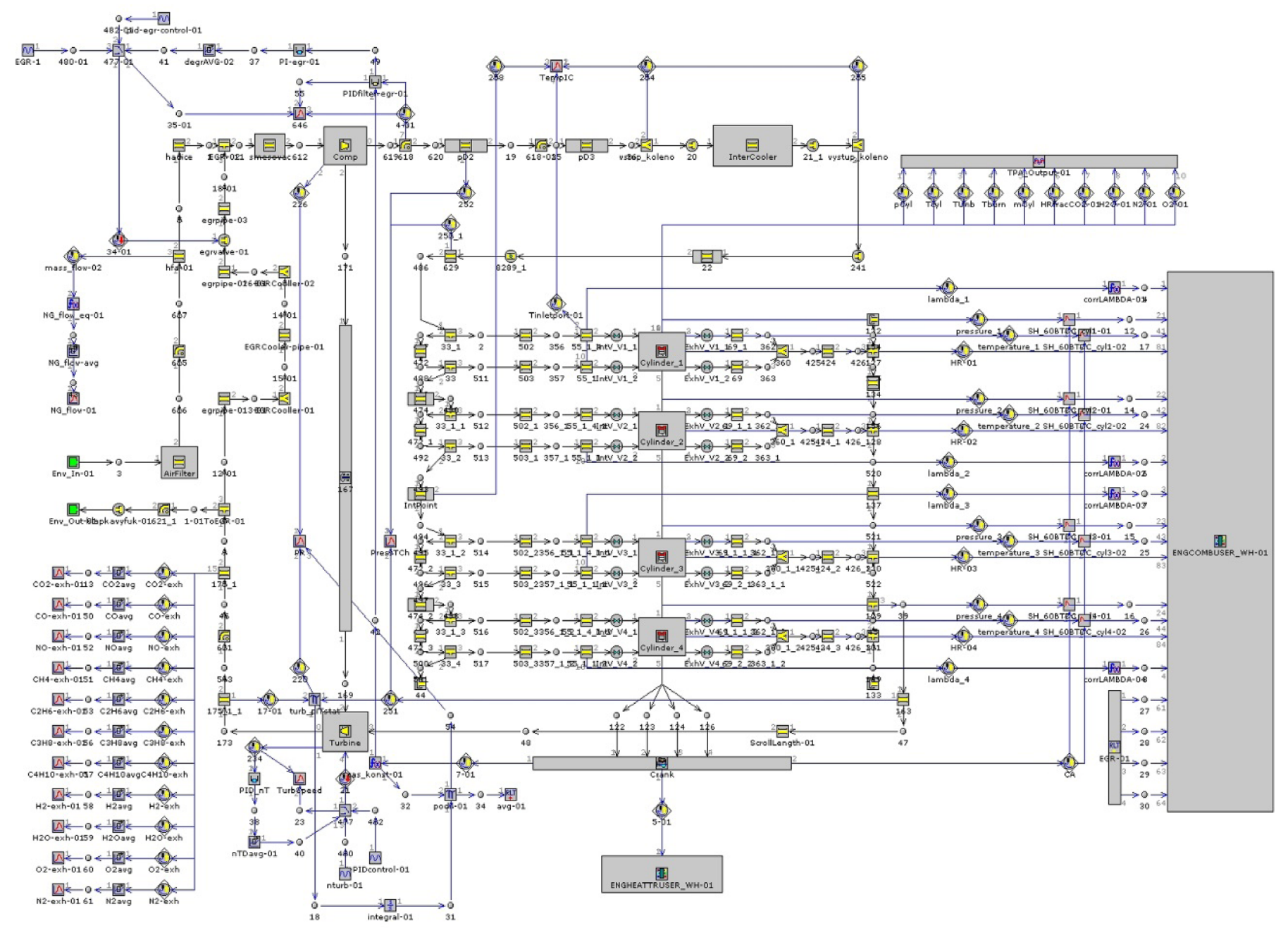

FIGURE 1: Engine Model Layout

OBRÁZEK 1: Uspořádání modelu motoru

well-proven methodology introduced by Csallner and Woschni $[7,8]$. The effect factors are polynomial functions of engine speed, ignition timing, residual gas content (or rather a sum of residual gas and external EGR), pressure and temperature at crank angle position $60^{\circ}$ BTDC. An extended set of polynomial coefficients was completed by coefficients depending on the mass fraction of these gases: $\mathrm{CO}, \mathrm{CO}_{2}, \mathrm{~N}_{2}, \mathrm{H}_{2}, \mathrm{C}_{2} \mathrm{H}_{6}, \mathrm{C}_{3} \mathrm{H}_{8}$ and $\mathrm{C}_{4} \mathrm{H}_{10}$. In any case, the rest of the fuel gas is methane. Particular values of these coefficients were determined by simultaneous calibration with determination of polynomial coefficients for operation parameters.

Inputs for determination of the HR pattern valid for a particular simulated working cycle consist of the angle-resolved description of the reference HR pattern and the set of above-mentioned effect factors. Typically the set of effect factors is tailored for a given design and operational features of the combustion system (combustion chamber geometry and charge movement nature and intensity), while the reference cycle is obtained from an in-cylinder pressure record acquired in typical operational conditions. Particular values of polynomial coefficients are determined by calibration. The range of validity can be restricted to a certain (limited) range of operational points in order to enhance accuracy and reliability of forward simulation results. On the other hand, the universal set of inputs can be used to enable model extrapolation within a wide range of operational conditions and/or design features of the combustion system. However, a generalized approach offers a lower accuracy of prediction for particular cases in comparison with one specifically tuned for the given case.

Multi-parametric linear regression was used for determination of individual effect factor polynomial coefficients. Since the effect factors are multiplied to determine the resulting angle position of significant HR points, the iterative procedure has been developed and tested such that assuming the known form of all but one effect factor, this factor regression is determined. Then, the procedure is repeated step by step for the other factors. This method has been called the "Heat Release Iterative Regression Method" $[9,10]$. 
The Burned Fuel Fraction (BF) pattern is more important as an input into the GT-Power main procedure than the HR pattern. Current versions of GT-Power are able to respect the combustion chemistry in a better way than previous ones, using zone models and local chemical equilibrium of combustion products. For this reason, the HR pattern is corrected to the BF pattern using an appropriate correction procedure.

For generation of the universal effect factors set, the calibration data were determined from measurements performed on three natural gas fuelled engines of various sizes, design features and operational ranges over a wide speed and load range with various adjustments.

The user knock model [11], which is derived according to [12], is used for simulation of knock. The basic strategy used for knock phenomenon model description is based upon the evaluation of the exhausted part of ignition delay in the end gas zone of the combustion chamber. This model is based on knowledge of the fuel methane number, the pressure and temperature of unburned mixture index designed angle and knocking when the index reaches one. Methane fuel and comparative numbers of the fuel were determined by [13].

The model for the production of nitrogen oxides is used to enable evaluation of the results of simulation calculations in terms of emission limits [14]. The standard GT-Power-zone model using the extended Zeldovich mechanism [15] is used to calculate the amount of nitrogen oxides produced by the engine.

\section{SIMULATION METHOD}

The whole simulation approach is based on the assumption that the most important engine parameter which has to be kept unchanged (when an engine operates with fuels of various compositions) is the effective power at a particular operating point of the full load curve. If this condition is fulfilled, the driveability of the vehicle will not be influenced by fuel composition variations. There is no reason for a change in friction losses due to fuel composition variations, therefore the exact mathematical expression of the "compensation of fuel composition variations" reads: $I M E P=$ const. During the simulations this condition was maintained as long as the potential control interventions offer sufficient maneuvering space. In the low speed range of the full load curve, where the turbocharger is unable to generate sufficient excess of boost pressure and the engine works without EGR delivery even if fuelled by a basic fuel, the inevitable power deterioration associated with the use of a weak fuel is determined by simulation.

The simulation strategy was adjusted in order to manage an increased number of degrees of freedom. For each simulated operational point, the optimum VTG rack position was first determined which leads to the highest obtainable IMEP taking into account real compressor and turbine maps. Subsequently, the range of investigated rack positions was trimmed into the area in which the IMEP consistently increases with decreased stator nozzle area (on account of exhaust back pressure).

The mathematical description of knock excitation was integrated into the user routine. In this way each simulation result contains information about knock tendency. It is expressed quantitatively by determination of figures of knock fraction.

\section{FORMATTING OF RESULTS AND PRESENTATION STRATEGY}

The increased number of degrees of freedom required the establishing of an appropriate presentation approach in order to ensure legibility of the results. As an illustration of the presentation formatting, samples were chosen which themselves display a certain segment of data which may be useful for the reader.

The plots in Figure 2 use the main control parameters (boost pressure and EGR rate) as independent variables. Each surface is valid for the given ignition timing. The content of carbon dioxide in the fuel blend which still does not prevent full compensation of the associated power loss by appropriate control adjustment is plotted along the vertical axis in this figure. This means that the content of $\mathrm{CO}_{2}$ in the blend will have to be situated between the surface and the $X-Y$ plane if the condition IMEP = const is to be met.

The indicated efficiency values are presented in Figure 3 for the same conditions as in Figure 2. The type of presentation shown in Figure 2 and Figure 3 depicts the relevant values in a compact and transparent manner. Of course, the presented examples do not offer the ability to work with the presented data quantitatively.

Figure 4 (left side) illustrates the projection into the horizontal plane of contours of the type of surfaces presented in Figure 2 and Figure 3. The figure is valid for one particular adjustment of ignition timing. This kind of diagram enables determination of a combination of boost pressure and EGR rate which maintains the original power and at the same time enables achievement of maximum obtainable efficiency for the given degree of weakening of the fuel properties due to the presence of carbon dioxide. The right diagram in Figure 4 enables judgment of the impact of the selected control adjustment concerning the main constraints, namely peak pressure, turbocharger speed and structure (represented by piston) temperature.

Results of the type presented in Figure 4 offer a quantitative expression of all relevant circumstances. Moreover, it describes exactly the limits. The left borderline in the graphs in Figure 4 describes the situation when the engine is operating on pure Transit Natural Gas (TNG). The right-hand borderline encloses 


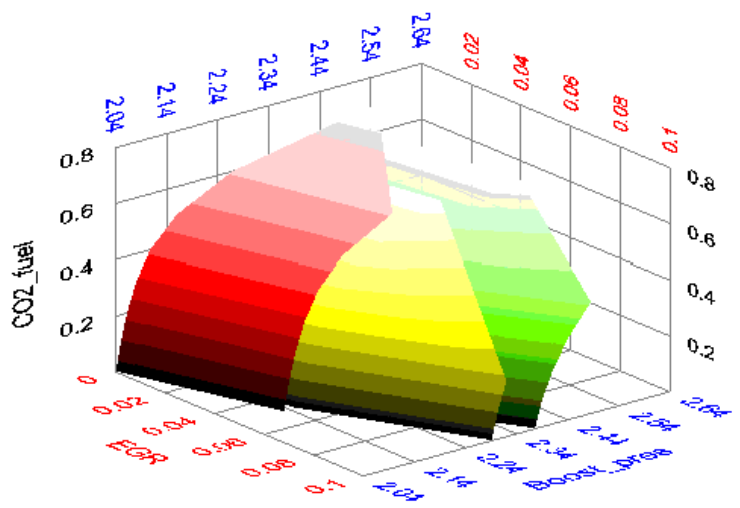

FIGURE 2: Acceptable Content of $\mathrm{CO}_{2}$ for Given IMEP Value OBRÁZEK 2: Akceptovatelný obsah $\mathrm{CO}_{2}$ pro danou hodnotu IMEP

the range in which the compensation of power loss is actually possible. It is impossible to keep the given (demanded) IMEP value using any combination of boost pressure control and EGR rate outside the boundary. The bottom right corner of the graph represents the absolute limit for the acceptable carbon dioxide content in fuel under the condition IMEP $=21$ bar. At this point the EGR is fully closed and VTG rack is adjusted to the position giving maximum IMEP.

The bundle of isolines as illustrated in Figure 4 can be considered an appropriate method for presentation of results when the presence of an additive ( $\mathrm{CO}_{2}$ in this case) in the fuel blend causes consistent deterioration of engine power which has to be compensated by an increase of boost pressure, restriction of EGR rate, or by a combination of both of them. It is to be expected that this kind of presentation will be less transparent if the influence of the fuel additive is not strictly consistent. Even if the graphs in Figure 4 offer a general insight into the issue at
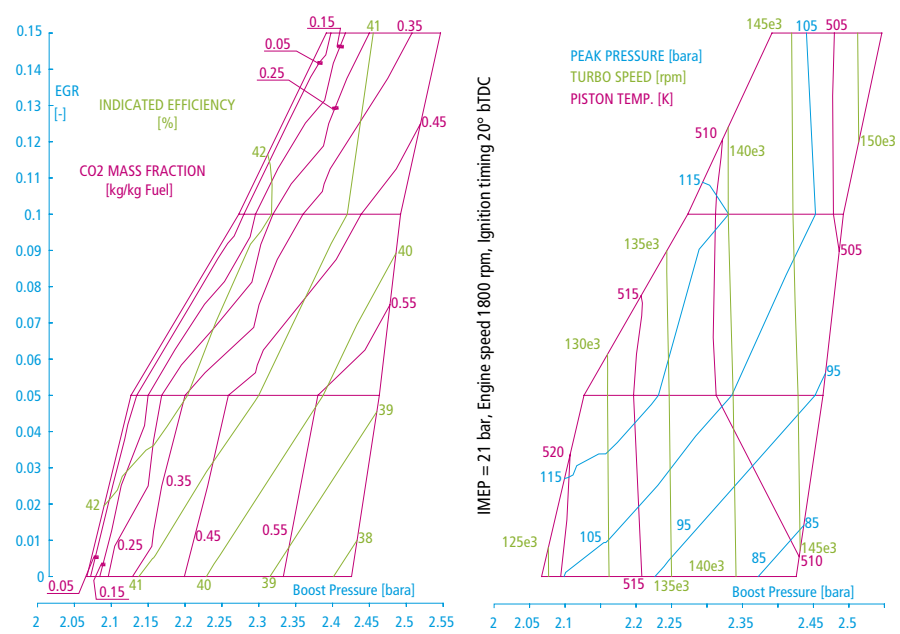

FIGURE 4: Options for Compensation of $\mathrm{CO}_{2}$ - Content in Fuel and their Impacts OBRÁZEK 4: Možnosti kompenzace $\mathrm{CO}_{2}-$ obsah v palivu a jeho vliv

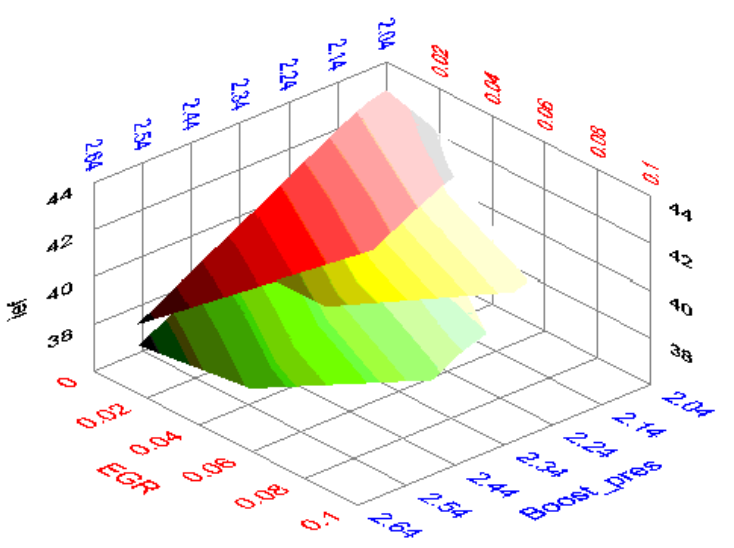

FIGURE 3: Indicated Efficiency Depending on Control Adjustments OBRÁZEK 3: Závislost indikované účinnosti na nastavení ř́zení

a glance, it is not appropriate for practical use, because typically the optimization task is defined as searching for an appropriate combination of control parameters for a given fuel composition. Therefore, it is appropriate to use additive content as one of the independent variables which enables user-friendly investigation of all relevant circumstances at a constant value of one graph coordinate. Figure 5 describes the same circumstances as the left part of Figure 4 , but this time the $\mathrm{CO}_{2}$ content is plotted along vertical axis while demanded boost pressure is presented as a bundle of isolines.

An example of constraints that have to be taken into account during the search for optimum adjustment is presented in Figure 6 . The coordinate system as used in Figure 5 and Figure 6 will be used for description of derivation of guidelines for compensation of the impact of fuel variation in all cases where an appropriate control of boost pressure and EGR in combination with appropriate adjustment of ignition timing enables original engine power to be maintained within a certain range of fuel composition variations.

Taking into account typical turbocharger behavior, it can be assumed that within the low speed range of the full load curve, the engine torque is restricted by achievable boost pressure. One of the important optimization sub-tasks during (any) engine development is to narrow this range as much as possible and to shift it outside the range of engine speed typically exploited during vehicle operation. An appropriate turbocharger(s) match, along with selection and application of suitable boost pressure control and the use of advanced non-conventional supercharging are the tools typically used to perform this task. Nevertheless, even if suppressed as much as possible, the low speed / low torque range of engine full load operation has to be taken into consideration especially in the case when weak fuel additionally worsens the engine power (at least to ensure completeness of the presented study). In this case it can be

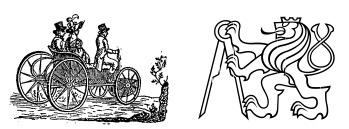


assumed that the engine is operating without any delivery of EGR and turbocharger control has been already adjusted to the position for maximum obtainable boost pressure. Ignition timing becomes the only remaining (usable) control parameter.

Figure 7 shows the isolines of achievable IMEP and associated indicated efficiency for various contents of $\mathrm{CO}_{2}$ in fuel, and various ignition timing adjustments. With the highest degree of probability the constraints are irrelevant within the discussed range of operational points because the danger of engine damage typically does not occur simultaneously with a lack of boost pressure and the associated power insufficiency.

All simulation results describe fuel composition in terms of mass fraction of particular additives.

\section{SIMULATION RESULTS}

A basic description of engine response to control parameters with various carbon dioxide contents in the fuel blend is presented in Figure 5. The patterns of values which have to be checked against acceptable limits are presented in Figure 6. Figure 8 describes the sensitivity of structure temperature (represented by piston temperature) to changes of fuel composition and control interventions. In the same Figure knock attitude is described being expressed quantitatively by values of knock fraction which refers to the fraction of the cylinder charge unburned at knock offset. In this case only very light knock occurs and most of the investigated range shows knock-free operation, as can be expected taking into account the inhibitive effect of $\mathrm{CO}_{2}$.

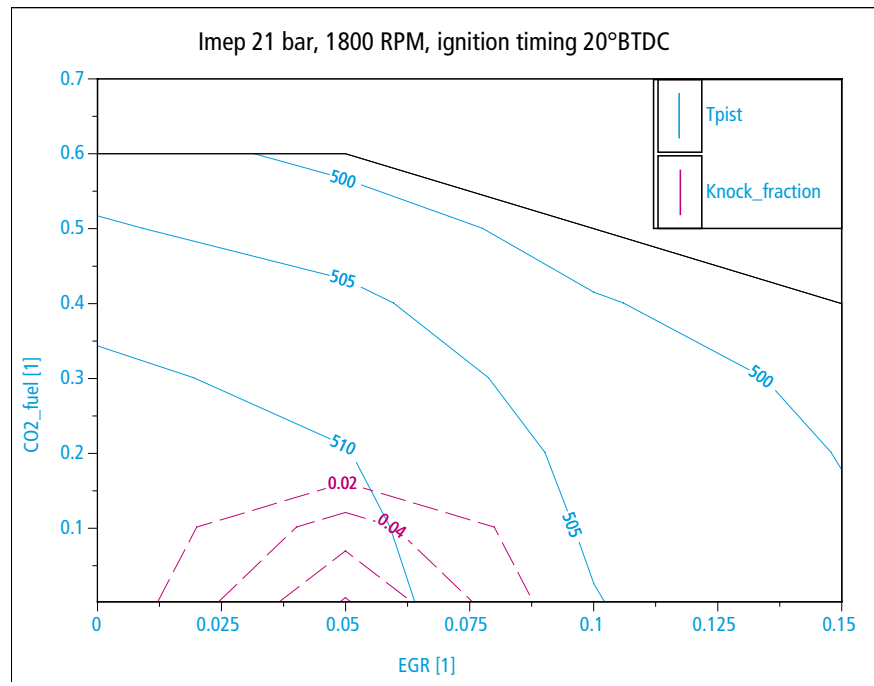

FIGURE 8: Piston Temperature and Knock Attitude Description with the Addition of $\mathrm{CO}_{2}$

OBRÁZEK 8: Teplota pístu a sklon ke klepání s př́idavkem $\mathrm{CO}_{2}$

The set of graphs as presented in Figure 5, Figure 6 and Figure 8 will be used for all fuel additives and all operational points that have been investigated. The graphs applicable in the case of the addition of propane to Transit Natural Gas

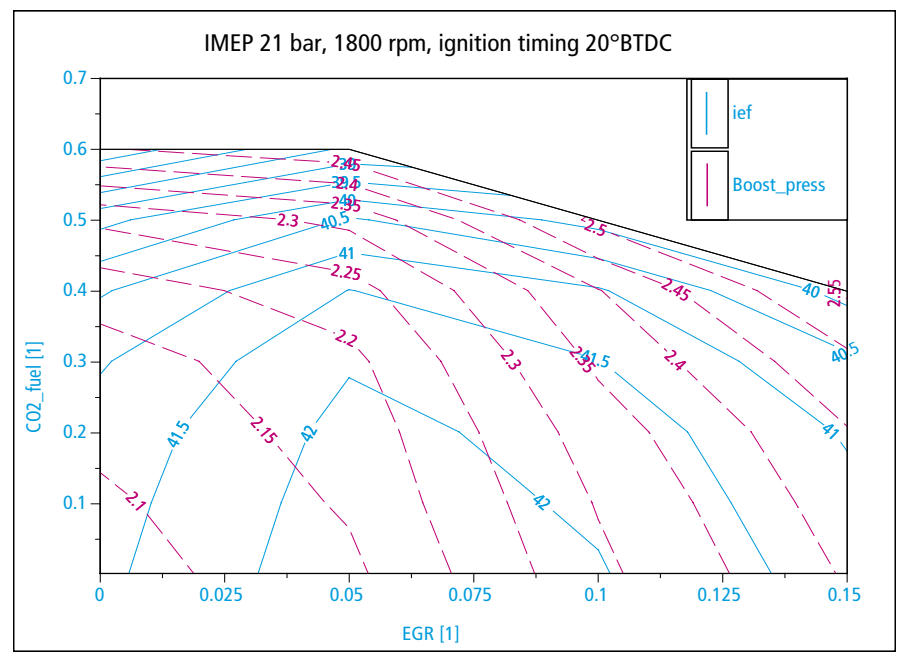

FIGURE 5: Engine Response to Control Parameters with the Addition of $\mathrm{CO}_{2}$ OBRÁZEK 5: Odezva motoru na rídící parametry s prídavkem $\mathrm{CO}_{2}$

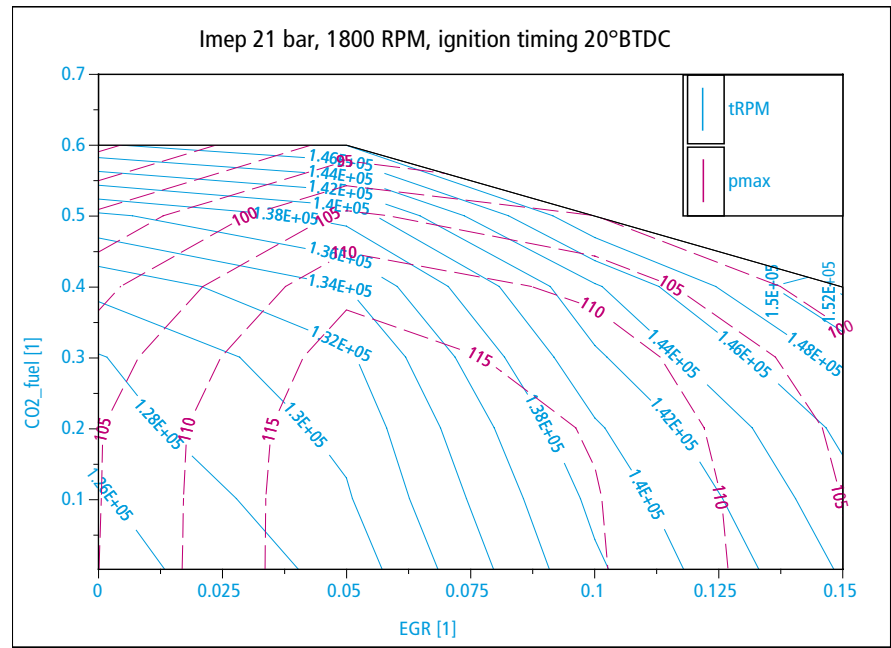

FIGURE 6: Constraint Patterns with the Addition of $\mathrm{CO}_{2}$ OBRÁzEK 6: Průběh omezujících parametrů s prí́davkem $\mathrm{CO}_{2}$

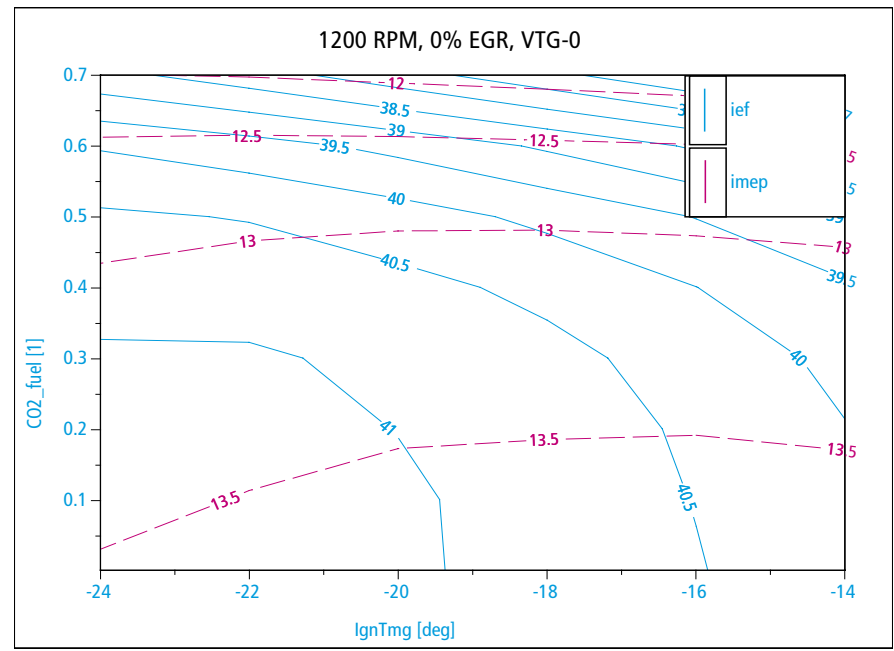

FIGURE 7: Engine Power and Efficiency at Low Speed - $\mathrm{CO}_{2}$-Containing Fuel OBRÁzEK 7: Účinnost a výkon motoru v nízkých otáčkách - palivo obsahující $\mathrm{CO}_{2}$ 
at $1800 \mathrm{rpm}$ and ignition timing $=20^{\circ} \mathrm{BTDC}$ are presented in Figure 9, Figure 10 and Figure 11. The graphs for the addition of hydrogen to Transit Natural Gas at $1800 \mathrm{rpm}$ and ignition timing $=20^{\circ} \mathrm{BTDC}$ are presented in Figure 12, Figure 13 and Figure 14. Figure 5, Figure 6 and Figures $8-14$ are representative enough for determination of generalized trends and values for the case where there are certain options to compensate fuel composition variation impacts by shifting control set-points. Similar figures for the addition of $\mathrm{CO}_{2^{\prime}}$ propane and hydrogen, 1600,1800 and $2000 \mathrm{rpm}$ and various ignition timings have been produced, but because of the scope of this article they are not listed. These figures are available on request from the author's (JBRC) archive.

The simulations were performed for mixtures of TNG with $\mathrm{CO}_{2}$, propane and hydrogen. The highest additive content in the investigated fuel exceeds the limit of real-life usability, which is estimated taking into account the availability of the component in general, on-board storage conditions (including dew point limitation) and potential impact on vehicle range. The only additional limitation of the investigated range was encountered with high $\mathrm{CO}_{2}$ content in fuel (especially in combination with high EGR rate - upper right corner of graphs in Figure 5, Figure 6 and Figure 8). In these cases the given turbocharger is not able to generate sufficient boost pressure to reach the demanded IMEP.

Boost pressure has to be generally increased with increasing amount of $\mathrm{CO}_{2}$ in fuel, while increasing the addition of propane calls for restriction of boost pressure in order to avoid (excessive) increase of engine power. The condition IMEP = const is met at (almost) unchanged boost pressure when hydrogen is added to the base fuel.

For each fuel additive all isolines of indicated efficiency show similar (almost identical) shapes. They are shifted vertically. This means that the optimum EGR adjustment remains unchanged for various fuel compositions, and equal to the optimum adjustment for the base fuel. Basically, the addition of $\mathrm{CO}_{2}$ decreases indicated efficiency, while addition of both propane and hydrogen improves efficiency. This statement is valid for each particular adjustment as well as along the optimum adjustment line.

The addition of $\mathrm{CO}_{2}$ improves knock resistance, which for any given fuel composition enables selection of the optimum EGR rate from the point of view of engine efficiency. On the other hand, the addition of both propane and hydrogen worsens the fuel knock resistance and forces adjustment of EGR towards higher values. Along the isolines of constant

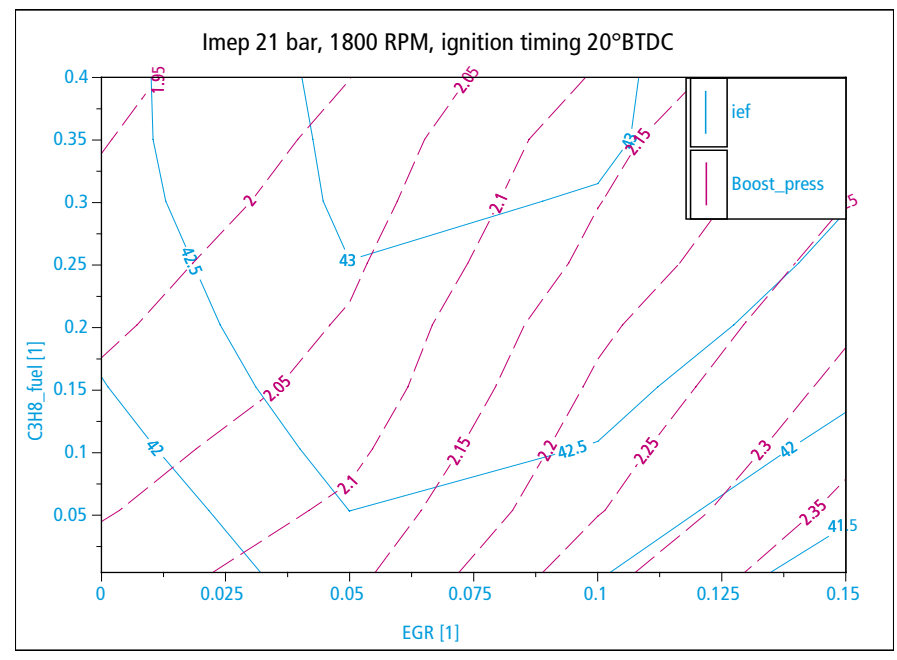

FIGURE 9: Engine Response to Control Settings - Addition of Propane OBRÁZEK 9: Odezva motoru na řídící parametry - přídavek propanu

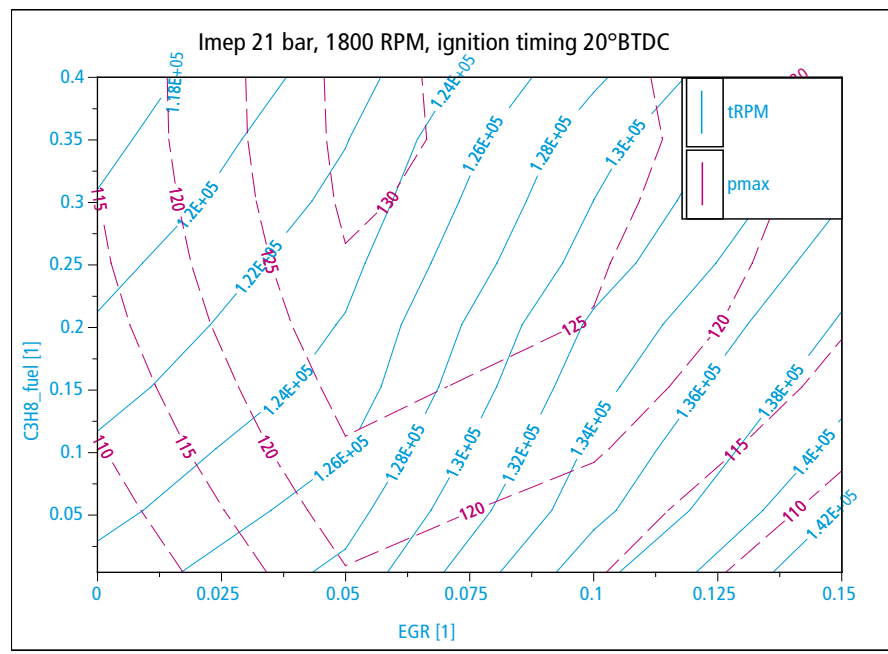

FIGURE 10: Peak Cycle Pressure and Turbocharger Speed - Addition of Propane OBRÁZEK 10: Maximální tlak ve válci a otáčky turbodmychadla prídavek propanu

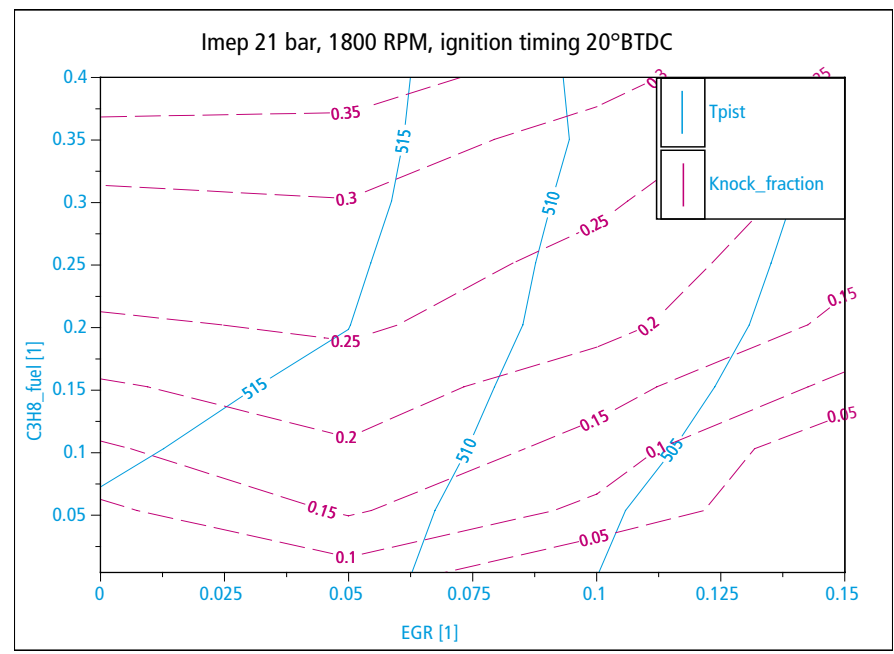

FIGURE 11: Piston Temperature and Knock Fraction - Addition of Propane OBRÁZEK 11: Teplota pístu a podíl klepání - př́davek propanu 
knock fraction (at the level of very light knock) the indicated efficiency maintains an approximately constant value for both these additives. The necessity to avoid knock narrows the maneuvering range; on the other hand, it simplifies the control algorithm - the engine is controlled to operate just on the knock boundary. This was also derived on the basis of previous experimental experience.

For the presented operating point, turbocharger speed and the piston temperature change slightly. Both of them maintain with the highest degree of probability sufficient safety margins (although the details will depend on the particular engine and/or accessory design). The properties of the fuel itself show the prevailing influence on peak cycle pressure while the induced demand for boost pressure change is of secondary importance. Therefore increased content of $\mathrm{CO}_{2}$ lowers peak cycle pressure even if it calls for boost pressure increase (in order to maintain IMEP = const.). Increased content of both propane and hydrogen increases peak cycle pressure even if, as in the case of $\mathrm{C}_{3} \mathrm{H}_{8^{\prime}}$ the engine operates with decreased boost pressure. In general, the mechanical stress is the most important constraint as is typical for engine operation whilst operating in the vicinity of maximum torque.

In the low speed part of the full load curve where turbocharger ability is insufficient to generate the desired boost pressure, ignition timing is the only control parameter available for optimization. The EGR line is typically fully closed and boost pressure control actuator is in the position for maximum turbine power.

Two characteristic points can be identified when the engine properties are investigated depending on ignition timing. The first of them represents the optimum setting from the point of view of indicator diagram shape. With this setting the engine reaches its optimum efficiency. When ignition is retarded from this point, the turbine power increases with increased exhaust temperature (increased enthalpy of turbine driving gas), and engine power (typically) increases thanks to the higher boost pressure, even if its efficiency worsens compared to the optimum. With further spark retardation the deterioration of in-cylinder pressure pattern outweighs the positive influence of rising boost pressure, and engine power decreases. Therefore, the engine designer has to select optimum ignition timing from the point of view of either efficiency or power, or choose an appropriate compromise between the two of them. This feature is not relevant within the range of the full load curve, where the turbocharger has sufficient excess power. When no constraints are relevant, the working cycle is optimized for the

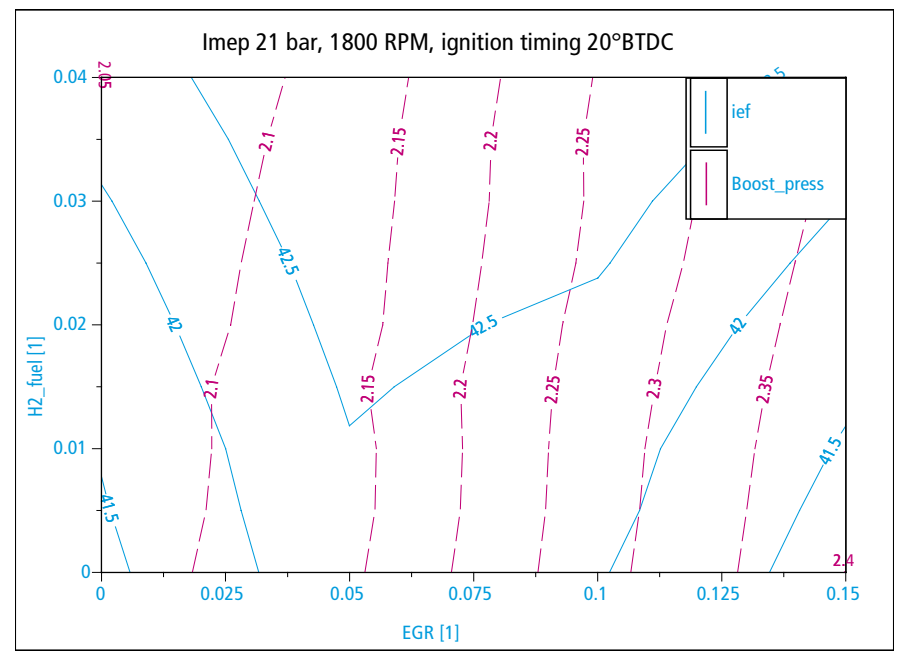

FIGURE 12: Engine Response to Control Settings - Addition of Hydrogen OBRÁZEK 12: Odezva motoru na řídící parametry - přídavek vodíku

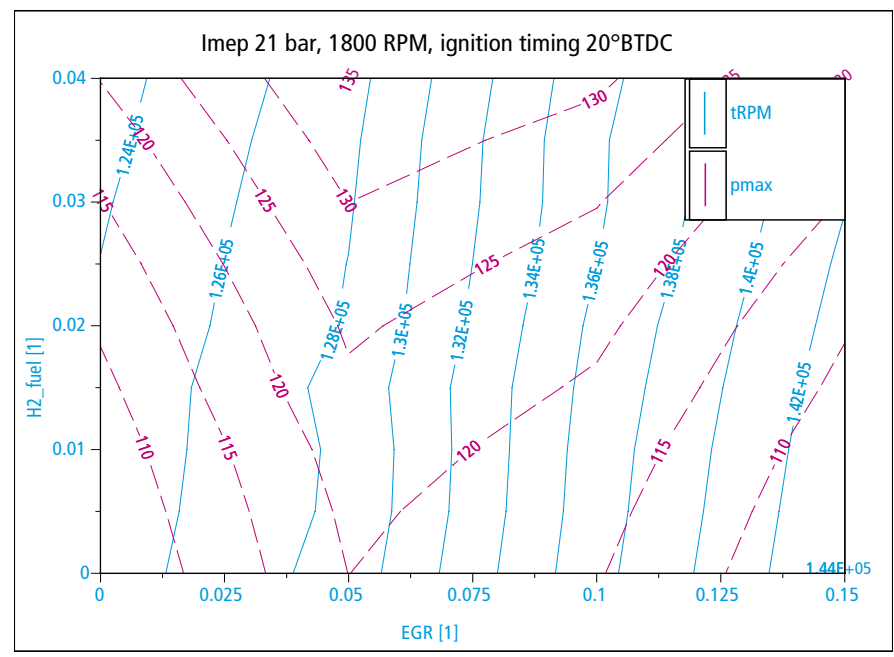

FIGURE 13: Peak Cycle Pressure and Turbocharger Speed - Addition of Hydrogen OBRÁZEK 13: Maximální tlak ve válci a otáčky turbodmychadla - prídavek vodíku

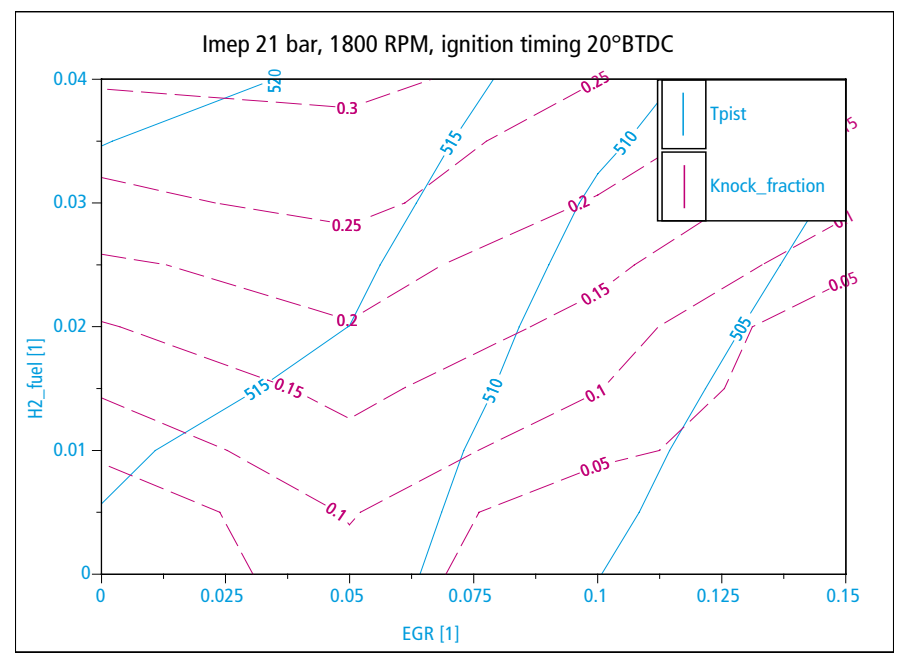

FIGURE 14: Piston Temperature and Knock Fraction - Addition of Hydrogen OBRÁZEK 14: Teplota pístu a podíl klepání - prídavek vodíku 


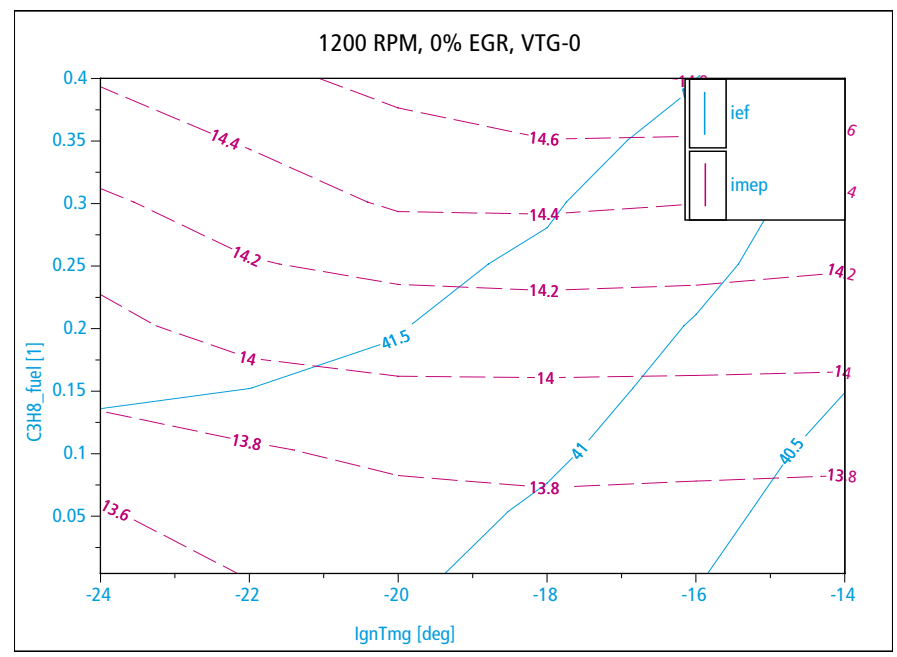

FIGURE 15: Engine Power and Efficiency - Low Speed - Propane Containing Fuel

OBRÁZEK 15: Účinnost a výkon motoru v nízkých otáčkách palivo obsahující propan

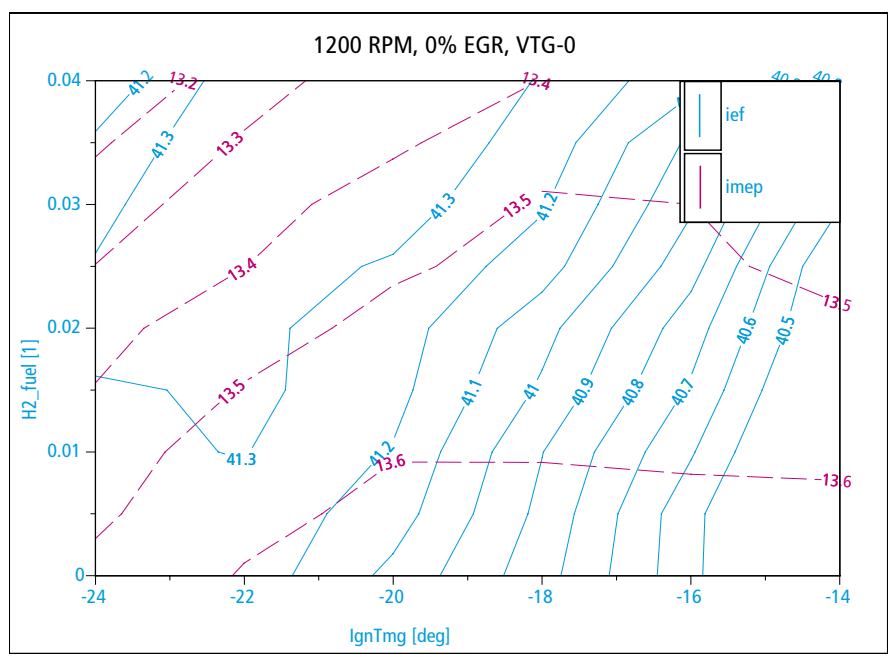

FIGURE 16: Engine Power and Efficiency - Low Speed - Addition of Hydrogen OBRÁZEK 16: Účinnost a výkon motoru v nízkých otáčkách - palivo obsahující vodík

maximum efficiency (this ignition timing strategy is valid for the medium and high speed part of the full load curve speed) and the desired power is adjusted by adjustment of boost pressure control. On the other hand, the existence of the two options for the optimum ignition timing adjustment at low speed is relevant for any fuel.

The basic properties of the engine operating with $\mathrm{CO}_{2}$ containing fuel at low speed are presented in Figure 7. The ability to achieve original power (= that obtained with the base fuel) depends on the originally implemented strategy of ignition timing adjustment. In any case, the maneuvering space is narrow and any readjustment of ignition timing aimed at increasing engine power is associated with an additional shift from the efficiency-optimized adjustment.

The presence of propane as a fuel component in general causes an increase of engine power (see Figure 15). This can be exploited to increase engine efficiency. If engine power (when fuelled with propane-containing fuel) is excessive (or is considered so), the methods are applied as described in the comments to Figure 9, Figure 10 and Figure 11, including knock-relevant considerations.

Additions of hydrogen cause a decrease in engine power due to lower mixture $\mathrm{CV}$, and decreasing exhaust temperature due to the high burning velocity (see Figure 16). Both mentioned features limit the ability to achieve original engine power, even if engine efficiency is actually improved by the addition of hydrogen.

At the high speed part of the full load curve (close to the rated or maximum speed) the whole situation is completely different. The only common feature is that the relevance of both of these marginal ranges depends on the circumstances which are proprietary to the particular engine and/or turbocharger design. Some considerations relating to restrictions on compensation for fuel composition variability during engine operation at high speed may in some cases be less important, or even irrelevant here. On the other hand, the options for optimizing turbocharger design, turbocharger match and boost pressure control range are not unlimited and it was considered correct to involve relevant circumstances into the study. During the engine operation, the limitations which have to be taken into account cause a narrowing of the range of possible control interventions. Boost pressure control is close to its "min" stop (fully open bypass at WG controlled turbocharger or maximum stator nozzle cross-sectional area), high EGR rate has to be adjusted in order to protect engine structure against overheating and ignition timing has to be carefully adjusted into the narrow gap between knock occurrence and excessive exhaust temperature at turbine inlet. Of course, simulations can be performed even outside the mentioned limits, but they are in fact also restricted in their range, especially by limits of the validity of turbocharger maps. In order to enable the presentation of the results within a certain range of operation points (to obtain non-zero area inside the graphs boundary enabling the observation of trends), it was decided to introduce the results of simulation performed at a speed of $2400 \mathrm{rpm}$. The same coordinate system and same distribution of isolines of particular physical quantities among individual figures was 


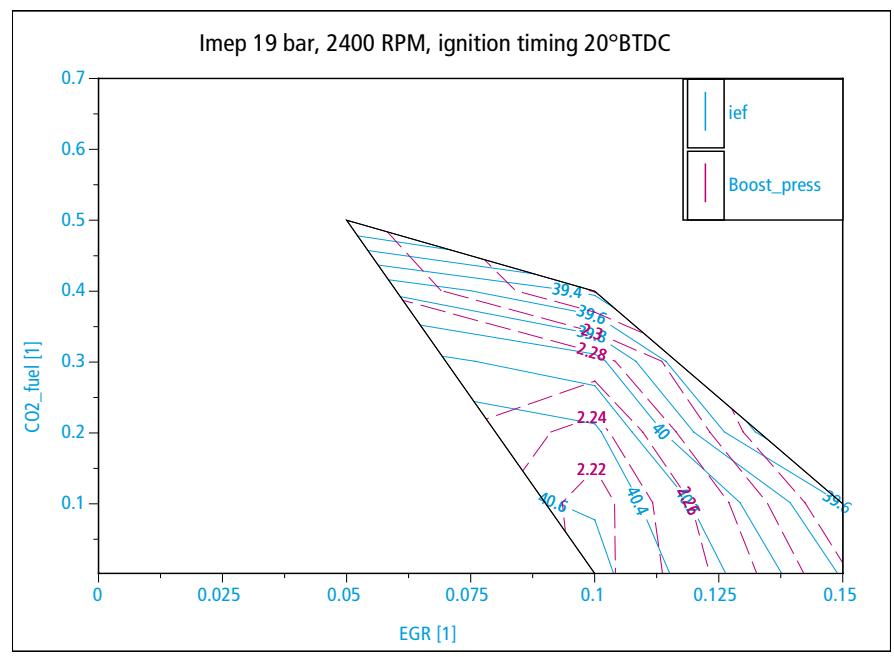

FIGURE 17: Engine response to Control Settings - Addition of $\mathrm{CO}_{2}$ OBRÁZEK 17: Odezva motoru na rídící parametry - prí́davek $\mathrm{CO}_{2}$

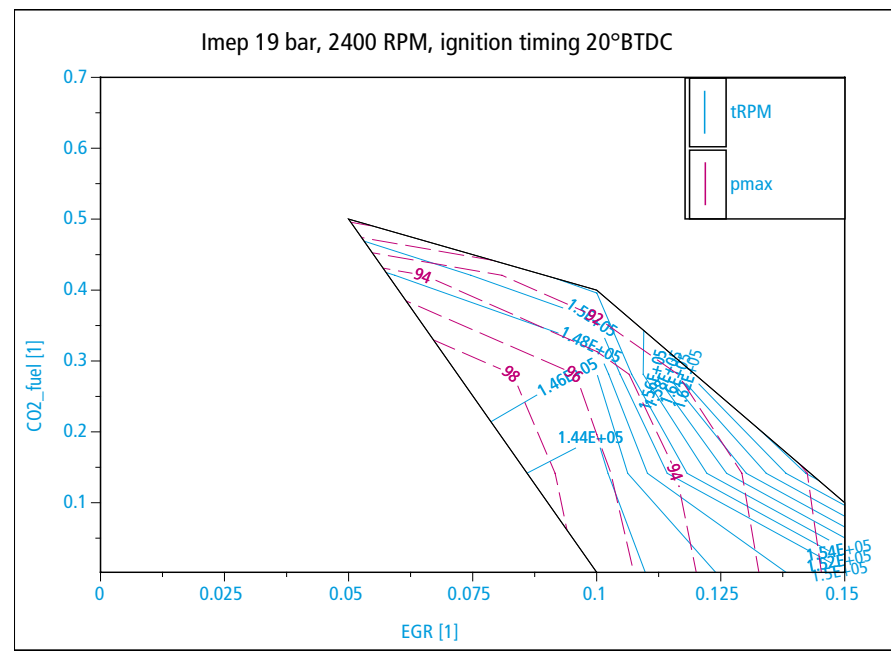

FIGURE 18: Peak Cycle Pressure and Turbocharger Speed - Addition of $\mathrm{CO}_{2}$ OBRÁZEK 18: Maximální tlak ve válci a otáčky turbodmychadla - prídavek $\mathrm{CO}_{2}$

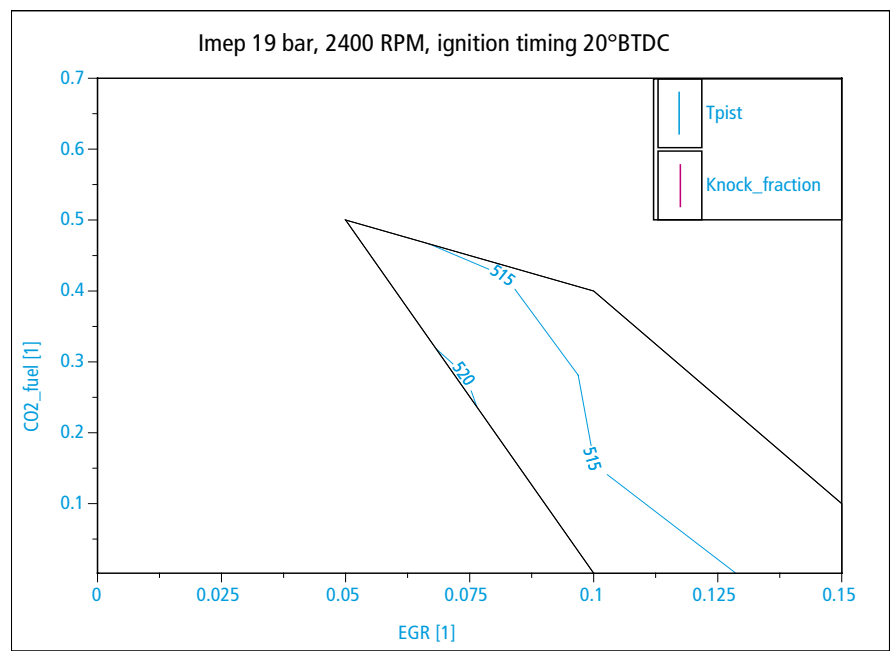

FIGURE 19: Piston Temperature and Knock Fraction - Addition of $\mathrm{CO}_{2}$ OBRÁZEK 19: Teplota pístu a podíl klepání - př́davek $\mathrm{CO}_{2}$ chosen as that used for presentation of the simulations valid for the medium speed range. The value of IMEP = 19 bar was chosen as the demanded (constant) indicated mean effective pressure.

Figure 17, Figure 18 and Figure 19 present the addition of carbon dioxide for engine operating point of $2400 \mathrm{rpm}$, fully open throttle and ignition timing of $20^{\circ}$ BTDC. The graphs applicable for the addition of hydrogen are shown in Figure 20, Figure 21 and Figure 22. Engine response to the addition of propane is shown in Figure 23, Figure 24 and Figure 25. Similar diagrams for the addition of $\mathrm{CO}_{2}$, propane and hydrogen, at $2400 \mathrm{rpm}$ and various ignition timings have been prepared, but because of the scope of this article are not listed. These figures are available on request from the author's (JBRC) archive.

The restriction of computational range is clearly visible in each presented graph even if the constraints are not taken into account. All graphs show limitations towards low EGR rate (and low $\mathrm{CO}_{2}$ or high propane content). Beyond this line (at lower EGR rates) the IMEP value is above the demanded value of 19 bar. Above the upper right borderline in Figure 17, Figure 18 and Figure 19 the content of $\mathrm{CO}_{2}$ in the fuel blend leads to deterioration of the engine power to such a degree that the IMEP value falls is below the prescribed one. Even if the boost pressure control actuator (VTG rack in this particular case) is close to its "min" position, it is impossible to increase the boost pressure due to the limitation of the turbocharger maps. This feature is demonstrated by the high density of isolines of turbocharger speed in Figure 18.

The graphs for $20^{\circ}$ BTDC ignition timing were included in the body of the study in order to maintain the continuity of presented circumstances. In general, advanced ignition timing increases engine efficiency, but it excites an unacceptable level of knock and it leads to increase of peak cycle pressure. In the case of addition of $\mathrm{CO}_{2}$ it is possible to exploit advanced ignition as a means to improve engine efficiency and to widen the range of acceptable content of $\mathrm{CO}_{2}$ in the fuel blend as long as the inhibitive effect of $\mathrm{CO}_{2}$ presence is sufficient to suppress the knock occurrence. By addition of both propane and hydrogen the knock occurrence becomes the main restrictive effect, which has to be treated by retarded ignition. The associated increase of exhaust temperature is almost certainly within acceptable limits as far as the advanced engines (and advanced turbochargers) are concerned. The negative impact of the presence of a knock-promoting component in fuel on exhaust temperature can be the topic of inquiry when the 


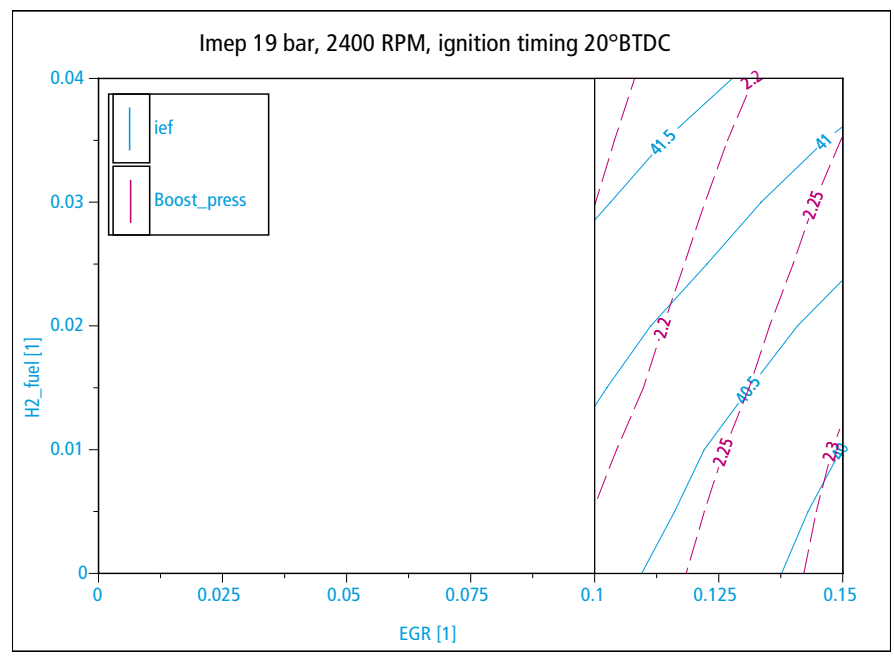

FIGURE 20: Engine Response to Control Settings - Addition of Hydrogen OBRÁZEK 20: Odezva motoru na rídící parametry - prídavek vodíku

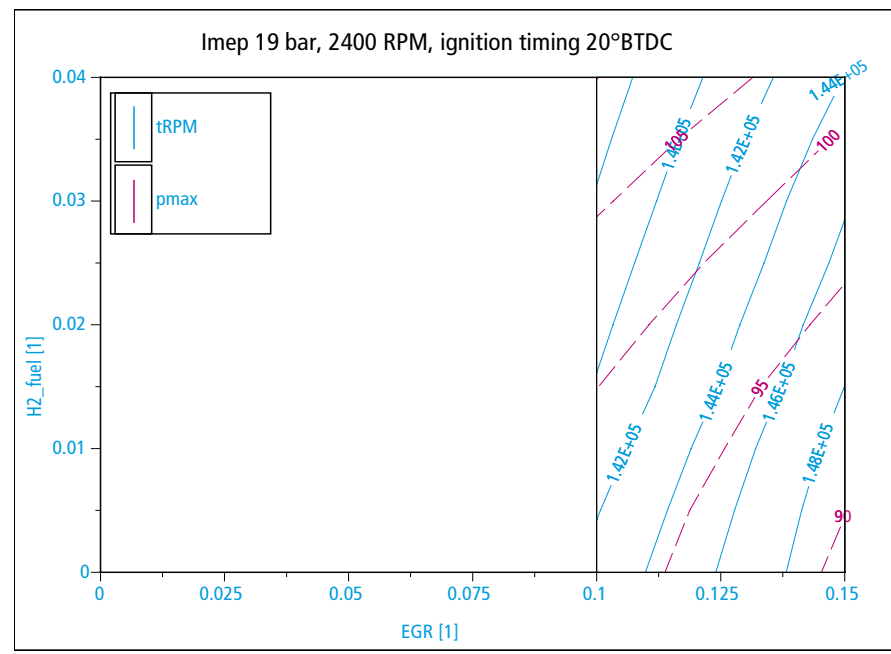

FIGURE 21: Peak Cycle Pressure and Turbocharger Speed - Addition of Hydrogen OBRÁZEK 21: Maximální tlak ve válci a otáčky turbodmychadla - prídavek vodíku

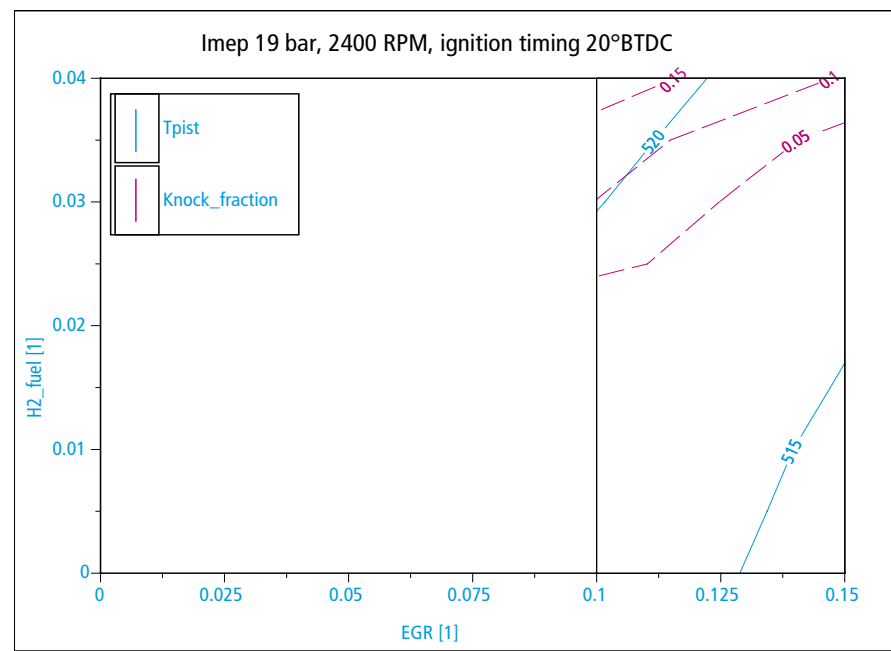

FIGURE 22: Piston Temperature and Knock Fraction - Addition of Hydrogen OBRÁZEK 22: Teplota pístu a podíl klepání - př́davek vodíku replacement of a WG-controlled turbocharger by a VTG one is the subject of consideration (if relevant).

Thanks to the implementation of high values of EGR rate, the engine structure thermal load can with, a high degree of certainty, be kept within the limits of acceptability. The appearance of both propane and hydrogen worsens the thermal load to a certain extent. In any case the thermal load of the engine parts has to be checked taking into account the particular engine design features.

The limitation of maximum allowable content of propane (excessive power at high content of propane) can be treated by throttling. It does not cause any significant problem with regards to engine working cycle thermodynamics, and the adjustment of throttle position depending on the actual operating point is a current branch of the engine control algorithm.

\section{CONCLUSIONS}

Three fuel additives were investigated using a simulation approach. $\mathrm{CO}_{2}$-containing fuel was chosen as a representative of a weak fuel with high content of an inflammable and inhibitive component. Propane was chosen as a representative of high gaseous hydrocarbons. The addition of hydrogen was investigated taking into account the intention of broadening the usable fuel range by introduction of hydrogen blended fuels ("hythane").

The first set of conclusions concerns the range of the full load curve in the vicinity of the speed at which the engine reaches its maximum torque. Taking into account real maps of the turbocharger (of a quite conventional VTG-controlled design) the original engine power can be achieved over the whole range of the tested additive contents. Therefore the torqueflexibility of the engine is not diminished by variation of fuel composition. Addition of $\mathrm{CO}_{2}$ in principle worsens the engine efficiency. This can be only partly compensated by the improved knock resistance of the fuel, which enables a control adjustment towards higher efficiency. Ignition timing and boost pressure generally have to be increased and the optimum EGR rate should be selected from the point of view of engine efficiency (adjustment of EGR towards lower values). On the other hand, the addition of both propane and hydrogen in principle improves the engine efficiency; however, this positive feature is restricted by the lower knock resistance of the blended fuel. Increasing the addition of propane and hydrogen requires adjustment of EGR towards higher values. The higher values of EGR rate demand an increase of boost pressure. Ignition timing should be set close to the knocking boundary. Finally the engine efficiency remains approximately the same as that obtained with unblended fuel 


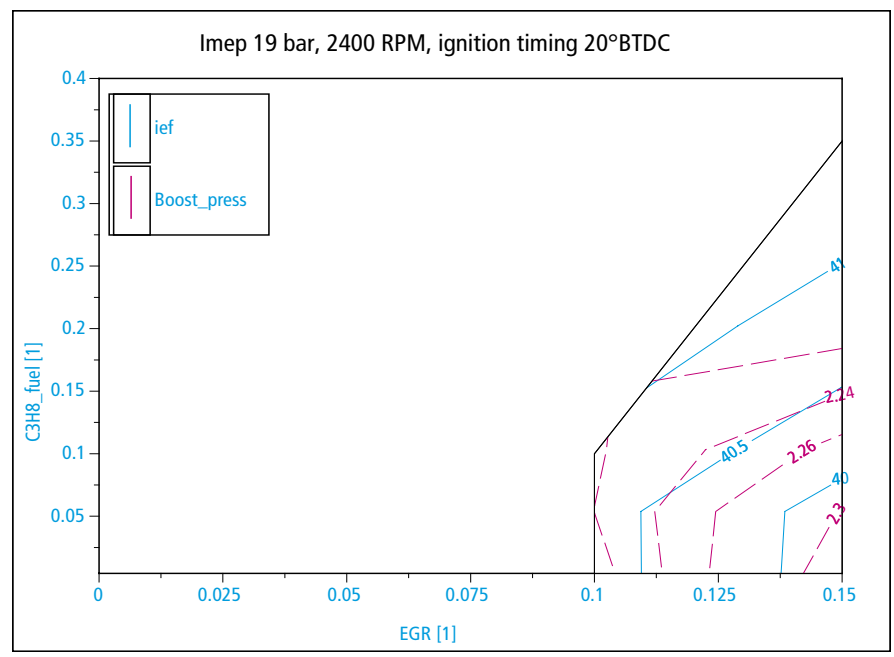

FIGURE 23: Engine Response to Control Settings - Addition of Propane OBRÁZEK 23: Odezva motoru na rídící parametry - prídavek propanu

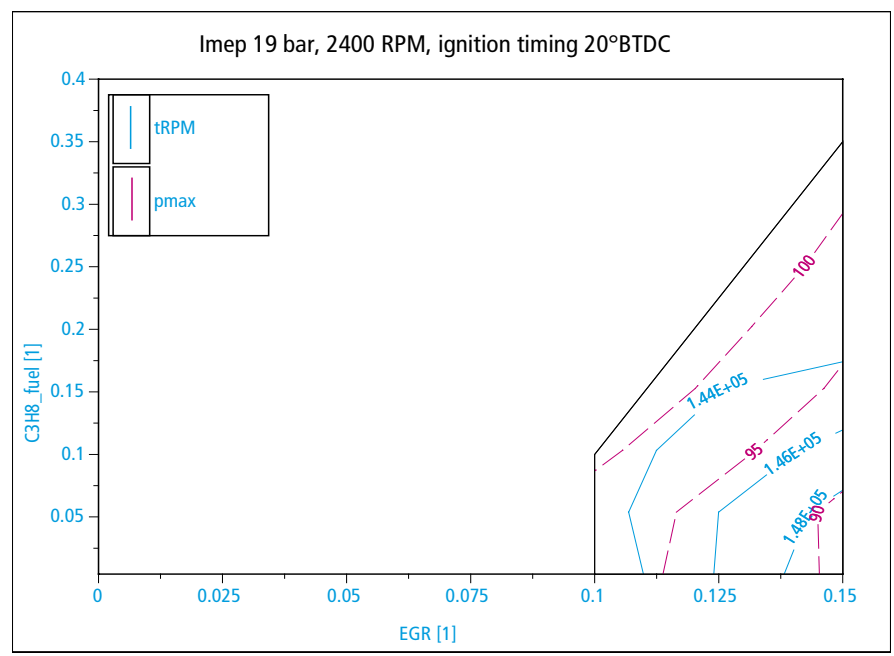

FIGURE 24: Peak Cycle Pressure and Turbocharger Speed -

Addition of Propane

OBRÁZEK 24: Maximální tlak ve válci a otáčky turbodmychadla prídavek propanu

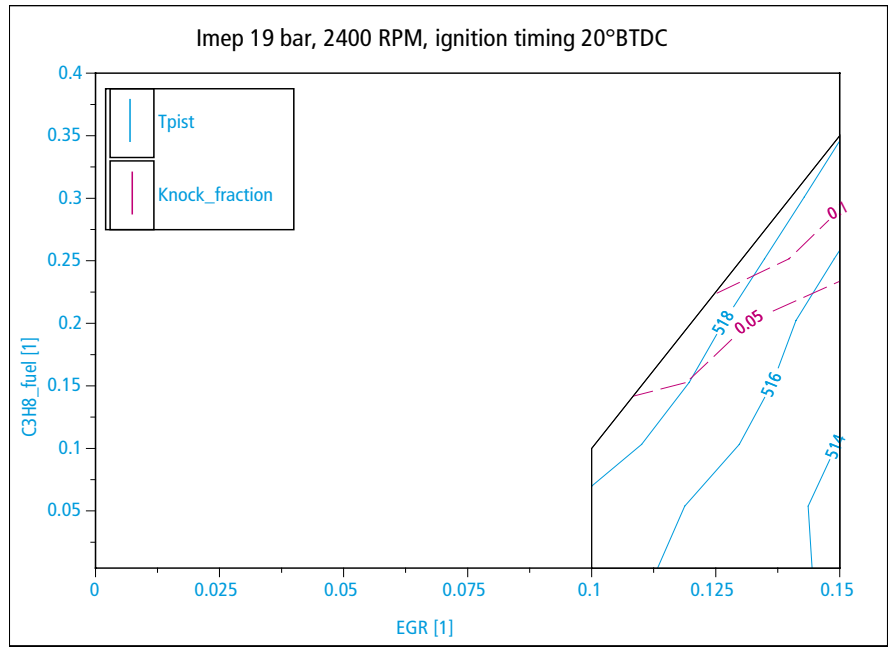

FIGURE 25: Piston Temperature and Knock Fraction - Addition of Propane OBRÁZEK 25: Teplota pístu a podíl klepání - přídavek propanu when knock-suppressing control interventions are implemented. The safety margins concerning turbocharger speed and structure temperature are not significantly influenced by fuel composition in general. The increase of peak cylinder pressure has to be checked against limits for the particular engine design.

Subsequent conclusions concern the low speed part of the full load curve where the turbocharger is not able to generate the desired boost pressure. The options for achieving the original engine torque with weak ( $\mathrm{CO}_{2}$-containing) fuel are significantly limited and associated with a decrease in engine efficiency. A decrease of ignition timing towards TDC produces insufficient torque increase. The addition of hydrogen deteriorates engine power due to its lower mixture $\mathrm{CV}$ in combination with higher burning velocity, which (even if it is otherwise favorable) causes lower exhaust gas temperature, turbine power and boost pressure. The mentioned circumstances outweigh the positive influence of improved efficiency, but it can be balanced by decreasing the ignition timing towards TDC. The addition of propane improves both engine power and efficiency. The only noteworthy restriction is increased knock tendency in common with the previously mentioned case - in the medium speed range. Ignition timing should be selected from the point of view of engine efficiency (adjustment towards higher values).

In the high speed part of the full load curve basically the same guidelines for control strategy are apply as those mentioned for the medium speed part. The differences are given by narrower maneuvering space due to more stringent constraints. Increasing ignition timing extends this space, and it should be set close to the knocking boundary.

\section{ACKNOWLEDGMENT}

The results presented in the article have been obtained as part of participation of the author's workplace in the Integrated project InGas Integrated Gas Powertrain - Low Emission, $\mathrm{CO}_{2}$ optimized and efficient CNG engines for passenger's cars (PC) and light duty vehicles (LDV) SCS7-GA-2008-218447.

$\begin{array}{ll}\text { LIST OF NOTATIONS AND ABBREVIATIONS } \\ \text { BF } & \text { burned fuel fraction } \\ \text { bTDC } & \text { before top dead centre } \\ \text { CV } & \text { calorific value } \\ \text { EGR } & \text { exhaust gas recirculation } \\ \text { HR } & \text { heat release fraction } \\ \text { IMEP } & \text { indicated mean effective pressure } \\ \text { LD } & \text { light duty } \\ \text { PC } & \text { passengers car } \\ \text { TNG } & \text { transit natural gas } \\ \text { VTG } & \text { variable turbine geometry } \\ \text { WG } & \text { waste gate }\end{array}$




\section{REFERENCES}

[1] Škarohlíd M. (2011). Advanced engine control possibilities to react on fuel features. MECCA 9 (2), p. 29-44.

[2] GT-POWER - GT-Suite Version 6. 2-7. 1. (2011). Gamma Technologies Inc., USA

[3] Vávra J., Macek J., Vítek O., Takáts M. (2009). Investigation of Radial Turbocharger Turbine Characteristics under Real Conditions. SAE Paper No. 2009-01-0311

[4] Škarohlíd M. (2010). GTlusr70_dp - Dynamic linked library for GT-POWER version 7.0 [computer software]. Czech Technical University in Prague, Czech Republic.

[5] Škarohlíd M. (2010). GTlusr62_dp - Dynamic linked library for GT-POWER version 6.2. [computer software]. Czech Technical University in Prague, Czech Republic.

[6] Vávra J., Takáts M. (2004). Heat Release Regression Model for Gas Fuelled SI Engines. SAE Paper No. 2004-01-1462

[7] Csallner P., Woschni G. (1982). Zur Vorausberechnung des Brennverlaufes von Ottomotoren bei geänderten Betriebsbedingungen. MTZ 1982, No. 5

[8] Woschni, G., Anisits, F. (1974). Experimental Investigation and Mathematical Presentation of Rate of Heat Release in Diesel Engines Dependent Upon Engine Operating Conditions. SAE Paper No. 740086

[9] Škarohlíd M. (2010). Modelling of influence of Biogas Fuel Composition on parameters of automotive engines. SAE Paper No. 2010-01-0542

[10] Škarohlíd M. (2009). New Methods of Determination of Effect Factors for the Cumulative Combustion Rate. KOKA 2009. International scientific conference of the Czech and Slovak Universities, Departments and Institutions Dealing with the Research of Combustion Engines, Nitra 2009, Advances in Automotive Engineering, Volume I, p. 46-53. ISBN 978-80-552-0255-6

[11]Škarohlíd M. (2010). GTlusr71_dp - Dynamic linked library for GT-POWER version 7.1, [computer software]. Czech Technical University in Prague, Czech Republic.

[12] Klír V. (2010). Description of knock onset in a turbocharged gas engine. MECCA 8(2), p. 28-34. ISN 1214-0821

[13] METHV500 - Methane number calculation program version 5.00, Caterpillar Inc., USA, (1996).

[14] Takáts M. (1993). Spark ignition gas engine burned extremely lean mixture - the formation and decay of nitric oxide. Unpublished doctoral Dissertation, CTU in Prague.

[15] Heywood, J. B. (1988). Internal combustion engines fundamentals. USA: McGraw-Hill, Inc. 